to exhibit my patient without writing about him. But the third edition of my Index of Surgery contained th 3 following sentence: "Ollier, when resecting for injury, makes a longitudinal incision and saws longitudinally through the patella." When I confess to this reticence, I feel more as if I were boasting than acknowledging anything to be ashamed of. My operation was done on a boy, aged sixteen, on Sept. 11th, 1883, and the following extract is from the notes of Mr. H. H. Taylor, then house surgeon at the West London, now at Brompton Hospital : "Under ether, and antiseptically, a longitudinal incision was made over the joint. The patella was sawn through in the same direction. ...... The patella was wired." I thought at the time that 1 had done something new, and I should be the last person to reproach $\mathrm{Mr}$. Herbert Allingham for making the same mistake. 1 have made it a rule to avoid wasting my time in contesting claims of priority, and should perhaps have not begun this correspondence if $\mathrm{I}$ did not strongly disagree with $\mathrm{Mr}$. Allingham's estimate of the value of the procedure, which it would now be a graceful act of his to join me in naming "Ollier's." The mistake of crediting your journal with a report which did appear in a contemporary is surely of no significance. With your kind permission, I will, at an early date, publish in your columns a briefly reported series of erasions and excisions of the knee-joint, including the case just mentioned, and then state more fully than I can in this correspondence what experience has taught me about the choice of methods. I remain, Sirs, yours obediently,

Jan. 1887.

C. B. KEETLEY.

\section{REMOVAL OF THE UTERINE APPENDAGES.}

\section{To the Editors of The LANCET.}

Sirs,-It is only just now that I have seen the report published in THE LANCET for Jan. 1st, of the Leeds and WestRiding Medico-Chirurgical Society's November meeting, in which Mr. W. H. Brown is stated to have read notes of a case of removal of the uterine appendages under circumstances calling forth the unanimous condemnation of subsequent speakers. Had I noticed the record sooner I should have lost no time in asking to be allowed to remove the responsibility from Mr. Brown's shoulders to my own, inasmuch as the operation was mine, and Mr. Brown had obtained my full permission to relate the case at the Society's meeting. Unfortunately I was not present that evening, or the remarks which I should have had the opportunity of making might possibly have materially modified the criticisms and consequently the report, which, as it stands in your columns, must convey the impression that $\mathbf{M r}$. Brown has been guilty of performing an unnecessary and an unjustifiable operation. Moreover-although I am sure Mr. Mayo Robson, who, as secretary, is, I believe, responsible for the published abstract, had no desire to suggest that the operation had been undertaken without consultation-the stress he lays upon his own practice of always having a full consultation (whatever that may mean) before operating will lead many to the erroneous conclusion that in this case so necessary a precautionary measure had been omitted.

I am not concerned at present to discuss the ethics of pelvic surgery. I will only say on that point that, under precisely similar conditions, I should again act exactly as I did in this particular instance; and it may not be superfluous to add that in the case related by Mr. Brown, although as the operator I am prepared to assume my full share of responsibility, no fewer than three unanimous consultations were held with my colleagues, among whom are Mr. Wheelhouse and Mr. Mayo Robson, as well as Mr. Brown. I am, Sirs, very faithfully yours,

Leeds, Jan. 8th, 1887. T. R. JESSOP.

\section{ALCOHOL AS MEDICINE. To the Editors of THE LANCET.}

SIRS,-A recent remarkable County Court trial has attained a wide publicity. The widow of a member of a Phœnix total abstinence society brought an action against the society for the amount of death claim due on her late husband's decease. The society's defence was that the man had broken his total abstinence pledge (the Phonix insisting on absolute abstinence without medical exception) by taking some intoxicating wine ordered by his medical attendant. The judge was most righteously indignant at this truly infamous defence, but was compelled to yield to the defence on the ground that the man himself on his sick bed had accepted the return of his subscription and his exclusion from benefit.

On inquiry I am happy to find that this is an isolated society, and is not one of the great Phonix orders, leaders of which general bodies assure me that their action in such bonâ-fide circumstances would have been to pay the widow's claim. We all know the false medical pretences on which people are apt to father their teetotal pledge breaking, and also the loose way in which alcoholic intoxicants are sometimes ordered; but it ought to be thoroughly understood that the temperance cause is not responsible for such shocking, disgraceful, and unjust treatment of a man on his death-bed and his widow in her sorrow.

I am, Sirs, your obedieñt servant,

Grove-road, N.W., Jan. 8th, 1887. NoRMAN KERR, M.D.

** For the correct name of the particular "Lodge" see an Annotation on p. 139.-ED. L.

\section{PROMOTION IN THE ARMY MEDICAL SERVICE.} To the Editors of THE LANCET.

SIns,-Referring to your remarks regarding the Army Medical Service, will you permit me to say that your original comment, to the effect that a medical officer could not, by regulation, be promoted to the rank of Brigade Surgeon without having passed the required examination, was, in my opinion, perfectly correct, and your correspondent who took exception thereto wrong. If you will turn to those regulations, you will find that he has, notwithstanding the use of inverted commas, made an important omission. The words are not "promoted for distinguished service," but " medical officers of any grade promoted for distinguished professional service will be exempt from further examination." Moreover, paragraph 8 of the same regulations is that which is applicable to such a case, and it seems clear and specific enough. It runs: "He must, before he can be selected for promotion to the grade of Brigade Surgeon, establish before an examining board, appointed for the purpose by the Director-General, his efiliciency in the following subjects"--viz., those of the examination.

Jan. 10th, 1887. I am, Sirs, yours truly,

A Medical OfFicer.

\section{FRIENDLY SOCIETIES' MEDICAL ASSOCIATIONS AND THEIR INJURY TO MEDICAL PRACTICE.}

\section{To the Editors of THE LANCET.}

SIRs,-Having seen several letters in your valuable paper, complaining of the difficulty of qualified men getting work to do, and the replies stating that it was greatly owing to the employment of unqualified assistants, I must in justice say that $I$ consider it is more due to the springing up of late years of amalgamations of clubs called "friendly societies' associations," and on which head I have a right to speak, having unfortunately for many years been connected myself with one until lately, where the payments of the members and their wives are four shillings, and of children under eighteen two shillings \& year, for which small amount visits and medicine are included, and patients seen within a radius of three miles. I do not believe there are any provident dispensaries conducted at so low a rate of payment. We certainly had the honour to have two town councillors, and I do not believe I shall be wrong if 1 say three belonging to us, also some of their wives and children, all of whom derived the benefits of the association at the same magnificent scale of payment. There were numerous other members in good stations of life in the like category. The secretary, a paid official, an officer under the Local Government Board, also allowed his family to partake of the benefits of the society. The association numbered nearly 4000 members, and to visit, dispense, and attend midwifery there was the large staff of two medical officers, who did not get half the annual receipts or any augmentation of income from increase of members.

All I can say in conclusion is, that I warn young medical men from taking up such appointments, as they lower the 